\title{
Kepribadian Muhsin danTingkat Stres Mahasiswa Psikologi Islam UIN Antasari Dalam Menghadapi Covid-19
}

\author{
Iimmatul Chasanah, Mubarak, dan Yulia Hairina \\ Universitas Islam Negeri Antasari Banjarmasin
}

\begin{abstract}
The purpose of this study was to determine the personality level of Islamic Psychology Study Program students, to see the stress level of Islamic Psychology Study Program students and to see the relationship between the student's personality and the stress level of Islamic Psychology Department students. This research used field research with quantitative. The population of this study was the students of the Islamic Psychology Study Program at UIN Antasari Banjarmasin adding 565 students. The sampling technique uses probability sampling techniques. The research sample consisted of 113 students. The results of the study: 1) There is a significant relationship between Mushin personality and stress levels with a significance level of $0.001(p<0.050)$ and together it makes an effective contribution of 10.1\%. 1\% (25 people), medium intensity 58.4\% (66 people) and low intensity $19.5 \%$ (22 people). 3) Data on the results of stress levels in the high category $26.5 \%$ (30 people), medium intensity 62.8\% (71 people), and low intensity 10.6\% (12 people).
\end{abstract}

Keywords: stress; muhsin's personality; covid-19.

\begin{abstract}
Abstrak
Tujuan dalam penelitian ini untuk mengetahui tingkat kepribadian muhsin mahasiswa Prodi Psikologi Islam, untuk mengetahui tingkat stres mahasiswa Prodi Psikologi Islam dan untuk mengetahui hubungan antara kepribadian muhsin dengan tingkat stres mahasiswa Prodi Psikologi Islam UIN Antasari Banjarmasin. Penelitian ini menggunakan penelitian lapangan dengan kuantitatif. Populasi penelitian ini ialah mahasiswa Prodi Psikologi Islam UIN Antasari Banjarmasin berjumlah 565 mahasiswa. Teknik pengambilan sampel menggunakan teknik probability sampling. Sampel penelitian ini terdiri dari 113 mahasiswa. Hasil penelitian: 1) Terdapat hubungan yang signifikan antara kepribadian mushin dengan tingkat stres dengan taraf signifikansi $0,001(\mathrm{p}<0,050)$ dan secara bersama-sama memberi sumbangan efektif sebesar $10.1 \%$.2) Data hasil tingkat kepribadian muhsin diketahui dikategori tinggi $22.1 \%$ (25 orang), intensitas sedang 58.4\% (66 orang) dan intensitas rendah 19.5\% (22 orang). 3) Data hasil tingkat stres di kategori tinggi 26,5\% (30 orang), intensitas sedang $62.8 \%$ (71 orang), dan intensitas rendah 10,6\% (12 orang).
\end{abstract}

Kata Kunci: stres; kepribadian muhsin; covid-19.

Angka kejadian covid-19 pertanggal 27 April 2020 menurut data WHO telah mencapai 2.883.603 kasus dengan angka kematian mencapai 198.824 orang. Sedangkan jumlah penderita Covid-19 di Indonesia mencapai 9.069 kasus dengan angka kematian mencapai 
1.151 kasus (Sari, 2020). Dampak yang ditimbulkan dari Covid-19 tidak hanya dirasakan oleh bidang ekonomi, sosial, budaya, politik, akan tetapi kini dunia pendidikan telah merasakan dampak dari pandemi Covid-19 ini. UNESCO menyatakan bahwa sekitar 300 juta siswa di dunia mengalami terkendala terhadap kegiatan sekolahnya dan mereka di masa depan terancam hak-hak pendidikan mereka (TV, 2020). Dampak Covid-19 ini tidak terkecuali dirasakan oleh satu elemen saja, akan tetapi semua termasuk elemen pendidikan pun ikut merasakan dampak dari Covid-19 ini semua pengajaran kini dilaksanakan di rumah masing-masing melalui aplikasi yang tersedia atau menggunakan jaringan internet. Yang merasakan dampak Covid-19 tidak hanya sekolah akan tetapi perguruan tinggi pun ikut terkena imbasnya. Di mana kegiatan perkuliahan yang pada biasanya dilaksanakan secara langsung atau secara bertatap muka secara langsung di lingkungan kampus kini menjadi sistem pembelajaran secara online.

Perubahan yang terjadi secara tiba-tiba dan mengejutkan bagi mahasiswa hal ini dapat memberikan pengaruh ataupun dampak terhadap mahasiswa, mahasiswa mengalami stres, cemas, tekanan, dll. Hal ini sejalan dengan penelitian Melani Kartika Sari stres yang timbul pada diri mahasiswa pada masa Covid-19 ini dapat menimbulkan perubahan serta dampak dan tekanan bagi mahasiswa itu sendiri. Takut terhadap terjangkit penularan Covid-19, kesulitan dalam memahami materi perkuliahan daring serta keterbatasan aktivitas dan meras bosan selama stay at home juga menjadi stressor tambahan yang menimbulkan stres bagi mahasiswa selama masa Covid-19 ini. Selain itu, dampak yang dirasakan oleh mahasiswa mengalami stres saat Covid-19 ini mahasiswa juga mengalami cemas. Hal ini sejalan dengan penelitian Uswatun Hasanah, Ludiana, Immawati, dan Livana PH hasil penelitian menunjukkan bahwa mahasiswa mengalami kecemasan tingkat kecemasan sedang diketahui sebanyak 32 mahasiswa dan tingkat kecemasan ringan diketahui sebanyak 79 mahasiswa dengan kegiatan pembelajaran daring (Hasanah, 2020)

Dampak Covid-19 kini dirasakan oleh seluruh mahasiswa di seluruh Universitas di perguruan tinggi, termasuk mahasiswa Prodi Psikologi Islam pun mengalami hal yang sama. Mahasiswa Psikologi Islam merupakan mahasiswa atau seorang individu yang sedang menempuh bidang studi atau mata kuliah jurusan Psikologi Islam, di mana Psikologi Islam merupakan ilmu yang mempelajari tentang ilmu kejiwaan yang tidak hanya belajar teori barat tetapi juga berlandaskan keislaman, mereka menempuh pendidikan atau 
bidang studi atau kuliah Psikologi Islam. Ilmu Psikologi Islam dilirik sebagai: pola pikir, sistem pendekatan atau cara pandang dalam mempelajari ilmu Psikologi disebut sebagai ilmu psikologi menurut Abdul Mujib. Satu keutuhan cara berpikir dalam menafsirkan secara keseluruhan ajaran Islam yang dilihat dari sudut pandang ilmu psikologi. Atau dapat dikatakn sebagai" ilmu studi Islam yang memiliki hubungan dengan aspek perilaku mental individu secara sadar akan membentuk kualitas diri menjadi yang lebih baik dan akan memperoleh kebahagian dunia akhirat (Mujib, 2006).

Stres yang dialami mahasiswa akibat pandemi Covid-19 dipengaruhi oleh beberapa hal yang menjadi stressor penyebab stres. Stres terjadi karena faktor-faktor penyebab stres antara lain adalah adanya penyebab dari faktor budaya, kepribadian, kognitif, lingkungan, fisik serta strategi penanganan stres dan lain-lain, faktor penyebab stres menurut pandangan Santrock (Sari, 2020). Hal ini sesuai dengan penelitian Astri, Farida Halis Dyah Kusuma, dan Esti Widiani hasil penelitian menunjukkan terdapat hubungan antara faktor kepribadian terhadap pembentukan munculnya stres, terdapat pengaruh secara signifikan terhadap kedua variabel tersebut artinya kepribadian dapat memberikan pengaruh terhadap munculnya stres dengan nilai Sig. sebesar 0,008 (nilai Sig. 0,008 $\leq$ 0,050) dan dengan nilai correlation coefficient - 0,653 yang memiliki arah hubungan atau pengaruh negatif (Astri, 2018)

Kepribadian dalam Islam dipandang sebagai perilaku individu sebagai makhluk sosial yang diturunkan dari norma ajaran Islam yang berasal dari ajaran Al-Quran dan sunah. Kepribadian mukmin ialah kepribadian yang beriman. Kepribadian muslim merupakan kepribadian orang Islam, kepribadian yang menyerahkan diri, tunduk, patuh kepada Allah. Kepribadian muhsin merupakan suatu kepribadian yang dapat memperindah individu dalam pergaulannya dengan diri sendiri dan orang lain. Kepribadian muhsin dalam studi tematik qurani memiliki beberapa indikator yakni: berserah diri kepada Allah sehingga terhindar dari rasa takut dan sedih hati, menahan amarah dan tidak berbuat acuh tak acuh terhadap orang lain, tidak membuat dan mencari masalah, bersabar dan tabah dalam menghadapi segala cobaan dan persoalan, rela berkorban untuk menambah ketakwaan dan keutuhannya kepada Allah. Mencari, menggunakan dan memanfaatkan pemberian Allah secara baik dan benar, berusaha keras untuk mencari dan menempuh jalan menuju Allah agar terhindar dari jurang kesesatan dan kehancuran (Mujib, 2006). Berdasarkan dari uraian 
tersebut peneliti tertarik untuk melakukan penelitian yang berjudul:"Hubungan antara Kepribadian Muhsin dengan Tingkat Stres pada Mahasiswa Prodi Psikologi Islam UIN Antasari Banjarmasin dalam Menghadapi Covid-19".

Tujuan dilakukannya penelitian ini adalah untuk mengetahui tingkat kepribadian muhsin pada mahasiswa Prodi Psikologi Islam Universitas Islam Negeri Antasari Banjarmasin dalam menghadapi Covid-19. Untuk mengetahui tingkat stres mahasiswa Prodi Psikologi Islam Universitas Islam Negeri Antasari Banjarmasin dalam menghadapi Covid-19. Untuk mengetahui bagaimanakah hubungan antara kepribadian muhsin dengan tingkat stres pada mahasiswa Prodi Psikologi Islam Universitas Islam Negeri Antasari Banjarmasin dalam menghadapi Covid-19.

Manfaat secara teoritis dalam penelitian ini adalah diharapkan dapat menambah wawasan dan pengetahuan di bidang ilmu Psikologi Islam khususnya pada teori kepribadian muhsin dan teori stres. Serta dapat menjadi referensi tambahan bagi penelitianpenelitian berikutnya. Manfaat secara praktis dalam penelitian ini adalah sebagai berikut: bagi mahasiswa, diharapkan dapat memberikan pengetahuan untuk meningkatkan kualitas pribadi, khususnya kepribadian muhsin. Mahasiswa diharapkan dapat menerapkan kepribadian muhsin ini dalam kehidupannya. Sehinngga dalam menghadapi berbagai macam situasi mahasiswa dapat tetap berperilaku baik. Bagi mahasiswa, diharapkan dapat memberikan pengetahuan untuk meningkatkan kualitas diri, dalam menghadapi berbagai macam situasi ataupun keadaan, mahasiswa diharapkan dapat mengontrol diri, mahasiswa dapat menjaga pikiran, perilaku, ataupun perasaan. Sehingga dalam menghadapi segala problem dalam kehidupan mahasiswa dapat terhindar dari stres. Bagi penelitian selanjutnya diharapkan dapat menjadi bahan referensi berikutnya.

Orang yang berbuat ihsan ataupun berprilaku ihsan merupakan kepribadian muhsin. Kata "ihsan" berasal dari kata "husuna" yang memiliki arti baik atau bagus. Kepribadian muhsin merupakan seluruh perilaku yang mendatangkan manfaat dan menghindarkan diri dari kemudharatan (Mujib, 2006). Kondisi individu yang disebabkan oleh interaksi antara individu dengan lingkungannya, yang menimbulkan persepsi jarak antara tuntutantuntutan berasal dari situasi yang bersumber pada sistem biologis, psikologis, dan sosial dari seseorang merupakan stres menurut Sarafino. Stres dapat terjadi karena akibat dari adanya tuntutan yang melebihi kemampuan individu. Seseorang yang tidak bisa memenuhi 
tuntutan tersebut akan merasakan ketegangan yang berlangsung lama dan tidak ada penyelesaiannya sehingga akan berkembang menjadi stres. Sarafino membagi aspek stres menjadi beberapa bagian diantaranya: aspek biologis, dan aspek psikologis yang terdiri atas, gejala kognisi, gejala emosi, dan gejala tingkah laku (Triyana, 2015). Hipotesis dalam penelitian ini terdapat hubungan antara kepribadian muhsin dengan tingkat stres pada mahasiswa Prodi Psikologi Islam UIN Antasari Banjarmasin dalam menghadapi Covid-19

\section{Metode}

Metode penelitian yang digunakan dalam penelitian ini adalah dengan jenis penelitian kuantitatif dengan jenis lapangan. Pendekatan dalam penelitian ini menggunakan pendekatan korelasional. Pendekatan korelasional digunakan untuk meneliti hubungan antara kedua variabel kepribadian muhsin dan tingkat stress mahasiswa Prodi Psikologi Islam. Universitas Islam Negeri Antasari Banjarmasin yang beralamat di Jl. A. Yani km. 4.5 Kelurahan Kebun Bunga Kecamatan Banjarmasin Timur di kota Banjarmasin Kalimantan Selatan adalah lokasi dalam penelitian ini. Subjek dalam penelitian ini adalah Mahasiswa Prodi Psikologi Islam Universitas Islam Negeri Antasari Banjarmasin. Objek atau variabel dalam penelitian ini adalah variabel independen dan variabel dependen. Variabel independen dalam penelitian ini ialah kepribadian muhsin dan variabel dependennya adalah tingkat stres

Dalam penelitian ini yang menjadi populasi ialah Mahasiswa Prodi Psikologi Islam Universitas Islam Negeri Antasari Banjarmasin yang berjumlah 565 mahasiswa. Sampel dalam penelitian ini dalah hanya mengambil sampel $20 \%$ saja dari populasi yang ada dengan demikian sehingga sampel dalam penelitian ini berjumlah 113 mahasiswa. Teknik pengambilan sampel dalam penelitian ini menggunakan taknik probability sampling yaitu teknik pengambilan sampel yang setiap pengambilan unsur atau anggota populasi memiliki peluang yang sama menjadi sampel. Sumber data primer dan sumber data skunder didapat dari informan.

Dalam penelitian ini respondenya yaitu Mahasiswa Prodi Psikologi Islam Universitas Islam Negeri Antasari Banjarmasin 113 mahasiswa. Sedangkan informan dalam penelitian ini adalah dosen di Prodi Psikologi Islam Universitas Islam Negeri Antasari Banjarmasin serta pihak lain yangg dapat memberikan informasi terkait penelitian. Penelitian ini hanya menggunakan dua skala yakni kepribadian muhsin dan tingkat stres. Alat ukur yang 
digunakan untuk mengukur kepribadian muhsin Mahasiswa Prodi Psikologi Islam Universitas Islam Negeri Antasari Banjarmasin dalam menghadapi Covid-19 dibuat sendiri oleh peneliti berdasarkan komponen-komponen yang ada di definisi operasional yang kemudian dideskripsikan lewat indikator yang ada di blue print. Adapun komponen kepribadian muhsin yang peneliti maksud di sini adalah ridha, raji, syukur dan muhibb. Alat ukur yang digunakan untuk mengukur tingkat stres Mahasiswa Prodi Psikologi Islam UIN Antasari Banjarmasin dalam menghadapi Covid-19 dibuat sendiri oleh peneliti berdasarkan komponen-komponen yang ada di definisi operasional yang kemudian dideskripsikan lewat indikator yang ada di blue print. Adapun komponen tingkat stres yang peneliti maksud di sini adalah biologis, psikologis. Adapun hipotesis dalam penelitian ini adalah terdapat hubungan antara kepribadian muhsin dengan tingkat stres pada mahasiswa Prodi Psikologi Islam UIN Antasari Banjarmasin dalam menghadapi Covid-19.

Analisis data pada penelitian ini menggunakan analisis statistik. Analisis data hasil penelitian, dimaksud untuk mengetahui hipotesis yang sudah dirumuskan peneliti. Setelah data diperoleh, maka peneliti melakukan analisis dengan metode deskriptif sesuai dengan pemahaman penulis. Sumber data dalam kajian ini terdiri dari dua, yakni data primer dan data sekunder. Data primer adalah data yang berkaitan dengan judul dalam penelitian ini, sementara data sekunder adalah data pendukung dari judul penelitian ini Untuk mengetahui hal tersebut peneliti menggunakan tehnik analisis uji korelasi. Uji korelasi digunakan untuk mengetahui hubungan antara kedua variabel tersebut.

\section{H a s i 1}

Penelitian ini di awali dengan pembagian skala kepribadian muhsin dan skala tingkat stres kepada mahasiswa Prodi Psikologi Islam UIN sebanyak 113 mahasiswa. Setelah melakukan penyebaran skala kepada mahasiswa selanjutnya data dianalisis dan menentukan model kategorisasi data berdasarkan skala kepribadian muhsin dan skala tingkat stres, selanjutnya dilakukan uji korelasi atau mencari hubungan antara kedua variabel tersebut. Berikut adalah data tabel yang akan menjabarkan tentang kategorisasi kepribadian muhsin dan tingkat stres pada mahasiswa Prodi Psikologi Islam UIN Antasari Banjarmasin dalan menghadapi Covid-19.

Tabel 1

Tingkat Kepribadian Muhsin 


\begin{tabular}{cccc}
\hline Kategori & Norma & Frekuensi & Persentase \\
\hline$X>103,24$ & Tinggi & 25 & $22.1 \%$ \\
$80,02 \leq X<103,24$ & Sedang & 66 & $58.4 \%$ \\
$X<80,02$ & Rendah & 22 & $19.5 \%$ \\
\hline
\end{tabular}

Berdasarkan tabel 1 di atas dapat diketahui bahwa tingkat kepribadian muhsin pada mahasiswa Prodi Psikologi Islam UIN Antasari Banjarmasin dalam menghadapi Covid-19 diketahui yang berada pada kategori tinggi sebesar 22.1\% yakni terdiri dari 25 mahasiswa, yang berada pada intensitas sedang sebesar 58.4\% yakni terdiri dari 66 mahasiswa, dan yang berada pada intensitas rendah sebesar 19.5\% yang terdiri dari 22 mahasiswa.

Tabel 2

Tingkat Stres

\begin{tabular}{cccc}
\hline Kategori & Norma & Frekuensi & Persentase \\
\hline$X>54,55$ & Tinggi & 30 & $26.5 \%$ \\
$39,90 \leq X<54,55$ & Sedang & 71 & $62.8 \%$ \\
$X<39,90$ & Rendah & 12 & $10.6 \%$ \\
\hline
\end{tabular}

Berdasarkan tabel 2 di atas dapat diketahui bahwa tingkat stres pada mahasiswa Prodi Psikologi Islam Universitas Islam Negeri Antasari Banjarmasin dalam menghadapi Covid-19 diketahui yang berada pada kategori tinggi sebesar 26,5\% yakni terdiri dari 30 mahasiswa, yang berada pada intensitas sedang sebesar $62.8 \%$ yakni terdiri dari 71 mahasiswa, dan yang berada pada intensitas rendah sebesar 10,6\% terdiri dari 12 mahasiswa. Selanjutnya peneliti melakukan uji korelasi pada kedua variabel tersebut adapun uji korelasi dalam peelitian ini sebagai berikut:

Tabel 3

Uji Korelasi

\begin{tabular}{llrr}
\hline & & Kepribadain Muhsin & \multicolumn{2}{c}{ Tingkat Stres } \\
\hline Kepribadain & Pearson Correlation & 1 & $-.318^{* *}$ \\
Muhsin & Sig. (2-tailed) & & .001 \\
& $\mathrm{~N}$ & 113 & 113 \\
\hline
\end{tabular}




\section{Tingkat Stress Pearson Correlation}

Sig. (2-tailed)

$\mathbf{N}$
$-.318^{* *}$

.001

113

Berdasarkan pada tabel 3 di atas dapat diketahui bahwa nilai signifikan padaantar variabel kepribadian muhin dengan tingkat stres adalah sebesar 0,001, artinya hipotesis pada penelitian ini diterima atau bersignifikan karena nilai tafar signifikan 0,001 dari penelitian ini lebih kecil dari 0,050 $(0,001 \leq 0,050)$, dengan demikian dapat disimpulkan bahwa dalam penelitian ini terdapat hubungan yang signifikan antara kedua variabel tersebut.Sehingga dapat disimpulkan bahwa terdapat hubungan antara kepribadian muhsin dengan tingkats stres pada mahasiswa Prodi Psikologi Islam UIN Antasri Banjarmasin dalam menghadapi Covid-19. Terdapat hubungan negatif antara kepribadian muhsin dengan tingkat stres pada mahasiswa Prodi Psikologi Islam UIN Antasari, sehingga semakin tinggi tingkat kepribadian muhsin maka akan semakin rendah pula tingkat stres pada mahasiswa Prodi Psikologi Islam UIN Antasari Banjarmasin dalam menghadapi Covid-19.

\section{Pembahasan}

Penelitian ini diketahui bahwa terdapat hubungan yang negatif dan signifikan antara kepribadian muhsin dengan tingkat stres pada mahasiswa Prodi Psikologi Islam UIN Antasari Banjarmasin dalam menghadapi Covid-19. Terdapat hubungan negatif sebesar 0.318. Tingkat stres mahasiswa dikategori tinggi sebesar $10.6 \%$ yakni terdiri dari 12 mahasiswa, terdapat intensitas sedang sebesar $62.8 \%$ yang terdiri dari 71 mahasiswa, dan intensitas rendah sebesar $26.5 \%$ yakni terdiri dari 30 mahasiswa. Selanjutnya menjawab rumusan masalah yang kedua tentang tingkat kepribadian mushin berada pada kategori tinggi sebesar $22.1 \%$ yakni terdiri dari 25 mahasiswa, yang berada pada intensitas sedang sebesar 58.4\% yang terdiir dari 66 mahasiswa dan yang berada pada intensitas rendah sebesar $19.4 \%$ yang terdiri dari 22 orang. Kemudian yang terakhir untuk menjawab rumusan masalah yang ketiga yakni mengenai apakah ada hubungan antara kepribadian mushin dengan tingkat stres pada mahasiswa Prodi Psikologi Islam UIN Antasari Bnajarmasin dalam menghadapi Covid-19, dari data hasil penelitian didapatkan hasil 
penelitian bahwa terdapat besar hubungan antara kepribadian muhsin dengan tingkat stres mahasiswa adalah $\left(r x y^{2} \times 100\right)$ yakni sebesar $10,1 \%$, artinya terdapat $10.1 \%$ saja kepribadian muhsin berpengaruh terhadap stres pada mahasiwa. Terdapat indikator lain sebesar $80.9 \%$ yang memiliki hubungan dengan tingkat stres pada mahasiswa selain kepribadian muhsin yang dalam hal ini tidak diteliti lebih dalam oleh peneliti.

Sesuai dengan hasil analisis data pada penelitian ini maka dapat ditarik kesimpulan bahwa terdapat hubungan yang negatif dan signifikan antara kepribadian mushin dengan tingkat stres pada mahasiswa Prodi Psikologi Islam UIN Antasari Banjarmasin dalam menghadapi Covid-19 dalam tingkat hubungan yang rendah atau memiliki tingkat pengaruh yang rendah variabel kepribadian mushin terhadap variabel tingkat stres, dapat dilihat dari persentase $10.1 \%$ tingkat stres mahasiswa dipengaruhi oleh kepribadian mushin, karena stres yang terjadi dan ada pada mahasiswa tidak hanya dipengaruhi oleh kepribadian mushin saja akan tetapi tingkat stres yang terjadi pada mahasiswa banyak dipengaruhi oleh faktor lain selain kepribadian muhsin, yakni sebesar $80.9 \%$ tingkat stres mahasiswa dipengaruhi oleh faktor lain selain kepribadian muhsin yang tidak diteliti lebih lanjut oleh peneliti.

Rendahnya hubungan antara variabel kepribadian muhsin dengan variabel tingkat stres ini dikarenakan stres yang dialami oleh mahasiswa tidak hanya dipengaruhi oleh kepribadian muhsin saja akan tetapi, stres yang terjadi pada mahasiswa banyak dipengaruhi oleh faktor lain selain kepribadian muhsin. Faktor lain yang mempengaruhi tingkat stres pada individu ialah karena faktor usia, jenis kelamin dan lain-lain sebaginya. Hal ini sesuai dengan ungkapan Stuart dan Laraia bahwa stres yang terjadi pada individu dipengaruhi oleh tingkat kedewasaan individu dapat dilihat dari usia dan pengalaman hidup (Mahmud, 2016). Penelitian lain yang dilakukan oleh Nasib Tua Lumba Gaol yang menyatakan bahwa dapat stres terjadi karena adanya faktor stimulus, respon dan transaksional. Stres yang terjadi karena faktor stimulus ialah karena adanya faktor penyebab stres yang berasal dari dalam diri individu (independen) yang menyebabkan individu menjadi stres. Misalnya pada situasi yang menekan perasaan individu dalam dirinya, stress juga dapat terjadi karena ada pemicu stres dalam diri seperti beban kerja, kepanasan, kedinginan, suara keributan, ruangan yang berbau, cahaya yang terlalu terang atau redup, lingkungan yang kotor, dan lain-lain (Goal, 2016). Stres yang terjadi karena faktor respon ialah terjadi karena 
adanya perubahan emosional yang dapat disebabkan oleh berbagai stressor penyebab stres, serta faktor lain-lain yang dapat menyebabkan stres pada individu (Wardana, 2016).

Kategori tingkat stres pada mahasiswa Prodi Jurusan Psikologi Islam UIN Antasari Banjarmasin berada pada ketegori sedang, dalam hal ini stres yang terjadi pada mahasiswa selama masa pandemi Covid-19 ini terjadi karena banyak faktor penyebab stres. Hal ini sejalan dengan penelitian Livana dkk hasil menunjukkan bahwa penyebab utama stres mahasiswa selama masa pandemi Covid-19 ialah "tugas pembelajaran". Stres yang terjadi pada mahasiwa selama masa pandemi Covid-19 ini juga dapat terjadi karena faktor lain yakni merasa bosan karena berada di rumah saja, proses belajar daring yang mulai membosankan, tidak bertemu dengan orang yang disayangi, tidak dapat melakukan pembelajaran online karena keterbatasan sinyal, tidak dapat melaksanakan hobi seperti biasanya dilakukan, tidak bisa melaksanakan pembelajaran praktik karena kekurangan alat dan ruangan $(\mathrm{PH}, 2020)$.

Pada kategori kepribadian muhsin pada mahasiswa Prodi Jurusan Psikologi Islam UIN Antasari Banjarmasin berada pada kategori sedang. Dalam hal ini terjadi karena dalam menjalankan kehidupan sehari-hari tidak hanya kepribadian muhsin saja yang memiliki peran penting dalam kehidupan. Pada faktanya mahasiswa yang berkuliah di Universitas Islam Negeri Antasari Banjarmasin memiliki karakter kepribadian yang berbeda-beda. Selain kepribadian muhsin ada kepribadian lain yang memiliki peran penting dalam kehidupan individu, misalnya kepribadian Muslim, kepribadian Mukhmin serta kepribadian lain yang dapat mempengaruhi tingkat stres pada mahasiswa. Kepribadian Islam berarti kepribadian Muslim, artinya Islam atau Muslim berarti kepribadian yang patuh, tunduk, menyerahkan diri, serta melaksanakan perbuatan yang baik agar selamat, bahagia dunia khirat (Mujib, 2006).

Kepribadian Mukmin berarti orang yang beriman. Iman memiliki arti pembenaran dalam hati, kepribadian Mukmin ialah meyakini dalam hati, mengucapkan dengan lisan dan mengamalkan dengan perbuatan. Begitu pentingnya iman dalam perbuatan karena iman ialah perjanjian ketuhanan yakni percaya dengan sepenuh hati kepada Allah adalah satu-satunya Tuhan di dunia akhirat. Serta percaya dengan aspek yang berhubungan dengannya seperti: meyakini para malaikat, kitab, rasul, hari kiamat, serta meyakini takdir Iman awal dari seseorang dalam meyakini Tuhan. Dengan demikian bisa saja individu yang 
memiliki tingkat kepribadian yang rendah ataupun sedang akan tetapi individu tersebut pada kepribadian lain memiliki kategori yang tinggi. Ihsan bermuara pada peribadatan di mana ketika sang hamba mengabdikan diri kepada Tuhannya sehingga perilakunya menjadi baik dan bagus hal ini menurut Hadits Nabi Muhammad saw. Kepribadian menurut Abdul Mujib ialah kepribadian yang dapat memperindah individu baik berhubungan dengan pribadi dan sesama. Hal ini sesuai dengan salah satu faktor pendukung stres yang baik ialah apabila individu memiliki kepribadian yang baik maka tingkat stres pun ikut membaik sebab apabila individu memiliki kepribadian yang baik iaakan dapat mengendalikan dirinya dengan sepenuhnya, serta ia dapat mengontrol dirinya dan keinginannya. Kepribadian dalam pandangan Islam memiliki sebuah arti yaitu serangkaian perilaku atau perbuatan manusia yang berlandaskan pada ajaran agama Islam yang bersumber dari Al-Quran dan Al-Sunnah (Mujib, 2006).

\section{Kesimpulan}

Dari hasil analisis data dalam penelitian mengenai hubungan antara kepribadian muhsin dengan tingkat stres pada mahasiswa Prodi psikologi Islam dalam Menghadapi Covid-19, maka dapat disimpulkan bahwa ada hubungan yang signifikan antara kepribadian muhsin dengan tingkat stres. Pengaruh yang diberikan sebesar 10,1\%.

Untuk hasil data penelitian kepribadian muhsin pada mahasiswa Prodi Psikologi Islam Universitas Islam Negeri Antasari Banjarmasin dalam menghadapi Covid-19 diketahui yang berada pada kategori tinggi sebesar 22.1\% yakni terdiri dari 25 mahasiswa, yang berada pada intensitas sedang sebesar 58.4\% yakni terdiri dari 66 mahasiswa, dan yang berada pada intensitas rendah sebesar 19.5\% yang terdiri dari 22 mahasiswa. Hasil ini menunjukkan bahwa kepribadian muhsin pada mahasiswa Prodi Psikologi Islam berada pada kategori sedang. Untuk hasil penelitian dari data tingkat stres pada mahasiswa Prodi Psikologi Islam Universitas Islam Negeri Antasari Banjarmasin dalam menghadapi Covid19 diketahui yang berada pada kategori tinggi sebesar 26,5\% yakni terdiri dari 30 mahasiswa, yang berada pada intensitas sedang sebesar $62.8 \%$ yakni terdiri dari 71 mahasiswa, dan yang berada pada intensitas rendah sebesar 10,6\% terdiri dari 12 mahasiswa. Untuk hasil tingkat stres pada mahasiswa Prodi Psikologi islam berada pada kategori sedang. 
Saran

Penelitian ini menunjukkan adanya hubungan antara kepribadian muhsin dengan tingkat stres pada mahasiswa Prodi Psikologi Islam UIN Antasari Banjarmasin dalam menghadapi Covid-19 untuk itu bagi pihak kampus khususnya Fakultas Ushuluddin dan Humaniora sebaiknya memudahkan mahasiswa dalam penelitian, hendaknya memperbanyak referensi-referensi ataupun buku-buku tentang Jurusan dan lain-lain sebagainya yang memudahkan mahasiswa untuk dengan mudah menyelesaikan skripsinya. Bagi mahasiswa diharapkan untuk bisa lebih meningkatkan kepribadian muhsin mereka dengan cara-cara yang sederhana misalnya, saling menolong antar sesama, menumbuhkan kasih sayang pada sesama mahasiswa. Diharapkan dapat memberikan referensi bagi penelitian selanjutnya.

\section{Referensi}

Abdul Mujib. Kepribadian Dalam Psikologi Islam. Jakarta: PT. Grafindo Persada, 2006.

Hasanah Uswatun, Ludiana, Immawati, dan Livana PH. Gambaran Psikologis Mahasiswa Dalam Proses Pembelajaran Selama Pandemi Covid-19. Jurnal Keperawatan Jiwa. Vol. 8, No. 3, 2020.

Livana PH., Mohammad Fatkhul Mubin, Yazid Basthomi. “Tugas Pembelajaran" Penyebab Stres Mahasisiwa Selama Pandemi Covid-19". Jurnal Ilmu Keperawatan Jiwa. Vol.3 No. 2, 2020.

Sari Melani Kartika. 'Tingkat Stres Mahasiswa SI Keperawatan Tingkat Satu Dalam Menghadapi Wabah Covid-19 Dan Perkuliahan Daring Stikes Karya Husada Kediri,“'dalam https://media.neliti.com/media/publications/327964-tingkat-stresmahasiswa-s1-keperawatan-t-251bf6e6.pdf, diakses pada 1 Oktober 2020.

Triyana Nurla Marlyn, Tuti Hardjani, dan Nugraha Arif Karyanta. Hubungan antara Resiliensi dan Stres dalam Menyusun Skripsi pada Mahasiswa Program Psikologi Fakultas Kedokteran Universitas Sebelas Maret'. Surakarta: Fakultas Kedoteran Universitas Sebelas Maret, 2015.

TV Kompas, "Dampak Corona ke Dunia Pendidikan" dalam https://www.kompas.tv/article/74608/sorotan-dampak-corona-ke-dunia-pendidikan, diakses pada 26 Oktober 2020.

Wardana Made Shanty dan I Made Krisna Dinata. Tingkat Stres Siswa Menjelang Ujian Akhir Semester Di Sman 4 Denpasar. E-Jurnal Medika. Vol. 5, No. 9, 2016. 


\begin{tabular}{|l|l|l|l|l|}
\hline Submit & Review & Revisi & Diterima & Publis \\
\hline 22-01-2021 & - & - & $02-06-2021$ & $04-02-2022$ \\
\hline
\end{tabular}

Iimmatul Chasanah, Mubarak, dan Yulia Hairina

Program Studi Psikologi Islam

Fakultas Ushuluddin dan Humaniora

Universitas Islam Negeri Antasari Banjarmasin

E-mail: IimmatulChasanahabdullah97@gmail.com 